\title{
Protein metabolism in the rumen of silage-fed steers: effect of fishmeal supplementation
}

\author{
BY J. M. DAWSON, C. I. BRUCE AND P. J. BUTTERY*, \\ Department of Applied Biochemistry and Food Science, University of Nottingham, \\ School of Agriculture, Sutton Bonington, Loughborough, Leicestershire LE12 5 RD \\ AND M. GILL AND D. E. BEEVER \\ AFRC Institute for Grassland and Animal Production, Animal and Grassland Research \\ Station, Hurley, Maidenhead, Berkshire SL6 SLR
}

(Received 14 September 1987 - Accepted 4 May 1988)

1. Ryegrass (Lolium perenne cy. Cropper) silage was given to four Friesian steers (initial live weight (LW) $172 \mathrm{~kg}$ ) alone or with a fishmeal supplement (150 g fresh weight $/ \mathrm{kg}$ silage dry matter (DM)) in a balanced twoperiod change-over design. The dietary components were the same as those used in a recent experiment by Gill et al. (1987). All diets were offered hourly at $24 \mathrm{~g} \mathrm{DM} / \mathrm{kg} \mathrm{LW}$.

2. Fishmeal supplementation increased dietary nitrogen intake $(P<0.01)$ and significantly increased the flow of total $\mathrm{N}(P<0.01)$, non-ammonia $\mathrm{N}(\mathrm{NAN})(P<0.01)$ and amino acids $(P<0.05)$ at the duodenum. The increased supply of NAN to the duodenum was due largely $(67 \%)$ to increased flow of undegraded dietary protein.

3. Microbial protein production was estimated simultaneously with ${ }^{15} \mathrm{~N}$, diaminopimelic acid (DAPA) and a novel technique using L- $\left[4,5-{ }^{3} \mathrm{H}\right]$ leucine. Estimates varied with the marker and source of microbial isolate but mean values indicated that microbial $\mathrm{N}$ flow was significantly increased by fishmeal supplementation $(P<0 \cdot 05)$. The use of $\mathrm{L}-\left[4,5-{ }^{3} \mathrm{H}\right]$ leucine as a microbial marker is justified and its possible advantages over other markers are discussed.

4. The efficiency of microbial protein synthesis was significantly increased from $30.8 \mathrm{~g} \mathrm{~N} / \mathrm{kg}$ organic matter apparently digested in the rumen (OMADR) to $54 \cdot 3 \mathrm{~g} \mathrm{~N} / \mathrm{kg}$ OMADR by fishmeal supplementation $(P<0.01)$. However, this indicates that relatively high efficiencies can be achieved with unsupplemented high quality silage supplied continuously. Rumen degradable $\mathrm{N}$ (RDN) supply was significantly increased by fishmeal supplementation $(P<0.05)$ but apparent efficiency of capture of RDN by rumen microbes was not significantly increased.

5. Attempts were made to investigate the source of $\mathrm{N}$ utilized by the microbes on the two diets by intrarumen infusions of $\left({ }^{15} \mathrm{NH}_{4}\right)_{2} \mathrm{SO}_{4}$ and $\mathrm{L}-\left[4,5-{ }^{3} \mathrm{H}\right]$ leucine but these were confounded by rumen-mixing problems. Findings obtained suggest that a lower proportion of microbial $\mathrm{N}$ may have been derived from rumen ammonia when the silage was supplemented with fishmeal but no differences in the extent of direct incorporation of leucine into microbial protein were observed. This could indicate an increase in microbial peptide uptake on the fishmealsupplemented diet. However, evidence was also obtained suggesting that the improvement in microbial protein synthetic efficiency with supplementary fishmeal was also due to the provision of a more continuous supply of nitrogenous substrates for microbial growth, as a result of hourly feeding.

6. The results are related to the increased growth responses attained by fishmeal supplementation of this silage in the experiment of Gill et al. (1987).

Young cattle fed on silage tend to show only low levels of live-weight (LW) gain which is believed to be due both to low voluntary intake of the silage and limiting protein supply. Both intake and LW gain responses have been obtained with fishmeal supplementation of silage diets in cattle (Forbes \& Irwin, 1970; Garstang et al. 1979; England \& Gill, 1985) although some workers have observed no increase in LW gain in response to fishmeal in the presence of other concentrate supplements (Steen, 1985). Much of this variation can be attributed to differences in the quality of the silages offered in these experiments and the greatest responses to fishmeal have generally been obtained with medium- or poor-quality silages. 
In a recent study by Gill et al. (1987), young growing steers offered high quality silage ad lib. showed increases in daily LW gain from 0.77 to $1.02 \mathrm{~kg} / \mathrm{d}$ in response to $150 \mathrm{~g}$ fishmeal $/ \mathrm{kg}$ silage dry matter (DM), with no increases in voluntary intake (mean $24 \mathrm{~g} \mathrm{DM} /$ $\mathrm{kg} \mathrm{LW}$ ). Carcass composition of the supplemented animals indicated significant increases in the content of crude protein (nitrogen $\times 6.25$ ), water and ash in the empty body, with no increase in fat weight relative to the silage-alone diet. This could be due to either changes in rumen metabolism or changes in body tissue metabolism, or a combination of both. The present study was undertaken to compare the rumen microbial metabolism of the silage and fishmeal-supplemented silage diets which supported these responses, and to consider the possibility that the improved growth response to fishmeal was due to a stimulation of microbial metabolism by the provision of preformed amino acids. The experiment was conducted with steers at a similar stage of growth and with a similar nutritional history to those used in the previous experiment (Gill et al. 1987). This paper also describes the use of a new marker, $\mathrm{L}-\left[4,5{ }^{3} \mathrm{H}\right]$ leucine, for estimating microbial protein production.

A preliminary report on part of this work has already been published (Dawson et al. 1987).

\section{MATERIALS AND METHODS}

\section{Diets}

The silage, taken from the same clamp as that used in the experiment of Gill et al. (1987), was prepared from a primary growth of perennial ryegrass (Lolium perenne cv. Cropper) harvested on 24 and 25 May 1984 with addition of formic acid (3.3 litres/tonne fresh grass) at the time of ensiling. Silage for the present experiment was removed from the silo in blocks, placed in $25-\mathrm{kg}$ sacks, blast frozen and stored at $-20^{\circ}$ until used. The silage was thawed at room temperature for approximately $48 \mathrm{~h}$ before use and was offered to the animals at $24 \mathrm{~g} \mathrm{DM} / \mathrm{kg} \mathrm{LW}$, the voluntary intake recorded by Gill et al. (1987) for steers of similar age. The fishmeal (Provimi 66, British White Fishmeals Ltd) was taken from the same batch as that used in the experiment of Gill et al. (1987) and was mixed with the silage by hand at $150 \mathrm{~g}$ fresh weight $/ \mathrm{kg}$ silage DM just before feeding.

\section{Animals and experimental design}

Four Friesian steers fitted with rumen fistulas and simple ' $T$ '-piece cannulas in the proximal duodenum (Beever et al. 1978) were housed in individual metabolism crates with constant illumination and free access to water and mineral licks. The animals were offered feed hourly from automatic belt feeders. Any feed refusals were removed daily and weighed. The experiment consisted of two periods each of about $20 \mathrm{~d}$ duration in a changeover design. In each period, two animals were offered silage alone and the other two were offered the fishmeal-supplemented silage. The second period began approximately 2 weeks after the end of the first period. During this 2-week period they were maintained on silage alone. Mean initial LW were $172 \mathrm{~kg}$ and $194 \mathrm{~kg}$ for periods 1 and 2 respectively. Adaptation periods of at least $7 \mathrm{~d}$ were allowed after introduction of the fishmealsupplemented diets. A 3-week initial adaptation period to the silage was employed for all animals.

\section{Experimental procedure}

Estimates of the rate of flow of digesta at the duodenum were obtained with a dual-phase marker system (Faichney, 1975), with ytterbium acetate as the particulate marker as described by Siddons et al $(1985 \mathrm{~b})$. Solutions of CrEDTA $(4.6 \mathrm{mg} \mathrm{Cr} / \mathrm{ml}$; Binnerts et al. $1968)$ and ytterbium acetate $(1.6 \mathrm{mg} \mathrm{Yb} / \mathrm{ml})$ were continuously infused, via separate infusion lines, into the reticulo-rumen by means of a peristaltic pump (Minipuls 2, Gilson, France) each at a rate of approximately $6 \mathrm{ml} / \mathrm{h}$ for a period of $10 \mathrm{~d}$. For the last $140 \mathrm{~h}$, 
$\mathrm{L}-\left[4,5-{ }^{3} \mathrm{H}\right]$ leucine $(5 \mathrm{mCi} /$ animal, $1 \mathrm{Ci} / \mathrm{mmol})$ and $\left({ }^{15} \mathrm{NH}_{4}\right)_{2} \mathrm{SO}_{4}(7$ atom $\%$ excess, $1170 \mathrm{mg}$ ${ }^{15} \mathrm{~N}$ ) were also infused, all infusions ending simultaneously.

Throughout the infusion period and for $30 \mathrm{~h}$ after the infusions were terminated, samples $(50 \mathrm{ml})$ of strained rumen fluid were taken four times daily $(06.00,11.00,16.00$ and 21.00 hours) by means of a syringe attached to a filtering device, while duodenal digesta samples $(100 \mathrm{ml})$ were collected by gravity flow from the ' $T$ '-piece cannula twice daily ( 06.00 and 16.00 hours). Bacterial fractions were isolated from these samples by differential centrifugation at $35000 \mathrm{~g}$ for $20 \mathrm{~min}$ at $4^{\circ}$ after removal of the feed particles $(1000 \mathrm{~g} \times 5$ $\mathrm{min})$. The microbe-free supernatant fraction obtained from the $7 \times 10^{5} \mathrm{~g}$.min spin was acidified with hydrochloric acid and stored at $-15^{\circ}$ for determination of rumen ammonia, $\mathrm{Cr}$ and volatile fatty acid (VFA) content. The bacterial fractions were washed once by resuspension in approximately $20 \mathrm{ml}$ McDougall's (1948) buffer, recentrifuged at $35000 \mathrm{~g}$ for $20 \mathrm{~min}$, and the pellet stored at $-15^{\circ}$ before freeze-drying. Not all the samples were analysed: for each animal, samples $(n \geqslant 6)$ for rumen ammonia, $\mathrm{Cr}$ and VFA analysis and bacterial $\mathrm{N}$ and diaminopimelic acid (DAPA) analysis were selected randomly. Bacterial fractions for analysis of $\left[{ }^{3} \mathrm{H}\right]$ leucine and ${ }^{15} \mathrm{~N}$ incorporation were selected from those isolated after at least $30 \mathrm{~h}$ infusion when incorporation of the isotope was shown from previous experiments (Bruce, 1986) to have reached a plateau.

On the 8 th day of marker infusion, duodenal samples were taken at 2-hourly intervals for $24 \mathrm{~h}$ and pooled on an equal-volume basis for each animal. Approximately $250 \mathrm{ml}$ of the mixed bulk sample was removed and freeze-dried to represent whole digesta, while another subsample (approximately $300 \mathrm{ml}$ ) was centrifuged at $1000 \mathrm{~g}$ for $5 \mathrm{~min}$ to obtain a digesta residue as an alternative digesta phase (Faichney, 1975) which was also freezedried.

Rumen fluid dialysates were obtained by incubating Visking tubing sacs (approximately $120 \mathrm{~mm} \times 22 \mathrm{~mm}$ diameter) filled with distilled water and contained inside weighted polyester bags in the rumen (Bruce et al, 1985). Bags were incubated in duplicate (two dialysis sacs/bag) suspended on $500-\mathrm{mm}$ lengths of nylon string and were changed every time a rumen sample was taken. On removal from the rumen, the polyester bags were washed thoroughly under running water and the contents of the dialysis sacs emptied into preweighed plastic containers and stored at $-15^{\circ}$ before analysis of $\left[{ }^{3} \mathrm{H}\right]$ leucine specific activity. Again, only samples obtained after at least $30 \mathrm{~h}$ infusion were analysed $(n \geqslant 10)$.

\section{Analytical methods}

Freeze-dried samples of feed, rumen and duodenal microbes and digesta were finely ground in a laboratory mill and stored dessicated. Feed samples were analysed as previously described (Gill et al. 1987). Organic matter (OM) content of duodenal digesta and microbial fractions was determined by ashing oven-dried $\left(105^{\circ}\right)$ samples at $550^{\circ}$ for $16 \mathrm{~h}$. Total $\mathrm{N}$ was determined by the micro-Kjeldahl technique with ammonia- $\mathrm{N}$ measured by the phenolhyperchlorite reaction (Davidson et al. 1970) on a Technicon AutoAnalyzer (Technicon Instruments Co. Ltd., Basingstoke, Hants). Ammonia- $\mathrm{N}$ content of duodenal digesta was determined after extraction with $0 \cdot 2 \mathrm{M}-\mathrm{HCl}$ for $30 \mathrm{~min}$ at $4^{\circ}$.

The $\mathrm{Cr}$ and $\mathrm{Yb}$ contents of rumen fluid samples and infusion solutions were determined by atomic absorption spectrophotometry (Varian AA-1275; see Siddons et al. 1985b). Duodenal digesta samples were ashed and extracted with nitric acid $(20 \mathrm{ml} / 1)$ containing $1000 \mu \mathrm{g}$ potassium/1 before analysis. VFA concentrations were determined by gas-liquid chromatography (Ryan, 1980).

${ }^{15} \mathrm{~N}$ enrichment of microbial $\mathrm{N}$, duodenal digesta non-ammonia $\mathrm{N}$ (NAN) and rumen ammonia was determined by mass spectrometry (Siddons et al. 1985a). DAPA contents of microbial fractions and duodenal digesta were determined according to Ling \& Buttery (1978). Amino acid analysis of feed, microbes and duodenal digesta was performed with 
lithium citrate buffers, on an LKB 4400 automatic analyser (LKB, Croydon) programmed to determine either whole amino acid profiles or, using a shortened system, to resolve the isoleucine, leucine and internal standard (nor-leucine and $\beta$-2-thienyl-D,L-alanine (TEA)) peaks only. The specific activity of $\left[{ }^{3} \mathrm{H}\right]$ leucine in microbial fractions and duodenal digesta was determined after acid-hydrolysis of the samples $\left(6 \mathrm{M}-\mathrm{HCl}, 22 \mathrm{~h}, 110^{\circ}\right)$ followed by thorough washing (three times) with distilled water and rotary evaporation to remove contamination from tritiated water. The radioactivity present in the washed protein hydrolysate was shown by split-stream cation-exchange chromatography using a Locarte Mk IV amino acid analyser (Locarte Co. Ltd, London) with lithium citrate buffers (Atkin $\&$ Ferdinand, 1970) to be associated entirely ( $>98 \%)$ with leucine and was measured directly by liquid scintillation counting with automatic external channels ratio quench correction (Packard Tri-Carb 4640, Berks). Leucine was determined by amino acid analysis as described previously and specific activity expressed as disintegrations/min (dpm) per $\mu$ mol leucine.

Rumen fluid dialysates were rotary evaporated to dryness and deproteinized with picric acid. After removal of the picric acid by ion-exchange chromatography (Dowex 2-X8, $200-400 \mathrm{mesh}$ ), the effluent was desalted by passing through a column of Dowex $50 \mathrm{~W}-\mathrm{X} 8$ (100-200 mesh, $\mathrm{H}^{+}$form) and eluted with $5 \mathrm{M}$-ammonium chloride. The effluent collected was rotary evaporated to dryness and thoroughly washed three times to remove ammonia and possible contamination from tritiated water. The specific activity of $\mathrm{L}-\left[4,5-{ }^{3} \mathrm{H}\right] \mathrm{leucine}$ was determined by preparative split stream ion-exchange chromatography (Locarte Co. Ltd) using lithium citrate buffer according to Atkin \& Ferdinand (1970).

During analysis of both rumen-free and protein-bound specific activities, nor-leucine was used to determine the recovery of the sample during its preparation and TEA was added to the sample before analysis on the column in order to estimate the proportion of the column effluent being directed to the fraction collector.

\section{Calculation of results}

Daily rumen liquid flow $(F)$ was calculated from the equation $F=I / C$, where $I$ is the infusion rate of $\mathrm{Cr}$ and $C$ is the concentration of $\mathrm{Cr}$ in rumen fluid at equilibrium. The fractional outflow rate of liquid from the rumen pool was determined from the rate of disappearance of $\mathrm{Cr}$ from the rumen after termination of the infusion. Rumen volume was calculated as the product of daily rumen liquid flow and the hourly turnover of the rumen pool.

Digesta flows were calculated after mathematical reconstitution of true digesta as described by Faichney (1975).

Microbial $\mathrm{N}$ flow estimated with $\mathrm{L}-\left[4,5-{ }^{3} \mathrm{H}\right]$ leucine was calculated as follows:

microbial $\mathrm{N}$ flow $(\mathrm{g} / \mathrm{d})=\left(\frac{\text { specific activity of duodenal digesta leucine }}{\text { specific activity of microbial leucine }}\right)$

$$
\times\left(\frac{\text { duodenal leucine flow }(\mathrm{g} / \mathrm{d})}{\text { leucine : total } \mathrm{N} \text { for microbes }}\right) \text {, }
$$

proportion of microbial $\begin{aligned} & \text { leucine from direct in- } \\ & \text { corporation of leucine }\end{aligned}=\frac{\text { leucine specific activity of microbial fraction }}{\text { leucine specific activity of rumen fluid dialysate at plateau }}$,

$\underset{\mathrm{N} \text { from rumen ammonia }}{\mathrm{p}}=\frac{{ }^{15} \mathrm{~N} \text { enrichment in rumen microbial fraction }}{{ }^{15} \mathrm{~N} \text { enrichment of rumen } \mathrm{NH}_{3}-\mathrm{N} \text { at plateau }}$. 
Table 1. Rumen indices in steers fed on silage with and without a fishmeal supplement

\begin{tabular}{|c|c|c|c|c|}
\hline & Silage & $\begin{array}{l}\text { Silage }+ \\
\text { fishmeal }\end{array}$ & SED & $\begin{array}{l}\text { Statistical } \\
\text { significance } \\
\text { of difference }\end{array}$ \\
\hline Rumen volume (l) & $30 \cdot 6$ & $27 \cdot 2$ & $0.57 \dagger$ & NS \\
\hline $\begin{array}{l}\text { Liquid phase fractional outflow } \\
\text { rate }(\mathrm{h})\end{array}$ & $0 \cdot 1086$ & $0 \cdot 106$ & $0.005 \dagger$ & NS \\
\hline Rumen liquid outflow $(1 / \mathrm{d})$ & 76.8 & 64.7 & $3 \cdot 43$ & NS \\
\hline Rumen pH & 6.71 & 6.61 & 0.025 & NS \\
\hline Rumen ammonia concentration (mM) & 7.84 & $10 \cdot 70$ & 0.448 & ** \\
\hline \multicolumn{5}{|l|}{ Molar proportion of VFA: } \\
\hline Acetate & 57 & 58 & 0.79 & NS \\
\hline Propionate & 29 & 29 & 0.56 & NS \\
\hline Butyrate & 14 & 13 & 0.90 & NS \\
\hline
\end{tabular}

SED, standard error of difference between means ( $2 \mathrm{df}$ except where indicated); NS, not significant. ** $\mathrm{P}<0.01$. $+1 \mathrm{df}$.

\section{Statistical analysis}

The response to fishmeal supplementation of silage was examined by analysis of variance. It should be noted that this statistical design leaves only 2 degrees of freedom for error, so caution must be exercised where no statistically significant effect of treatment is obtained. Comparisons of microbial $\mathrm{N}$ flow estimates with different markers and between estimates obtained with rumen- and duodenally-derived microbes were made by split-plot analysis of variance using animals, diets, microbial source and markers as the subplot strata. The level treated as not significant was $P>0.05$.

\section{RESULTS}

The silage used in the present experiment was the same as that used in a previous experiment by Gill et al. (1987) where a full chemical composition was given. Silage was well preserved with low $\mathrm{pH}$ and ammonia content. The DM content of the silage at $206 \mathrm{~g}$ $\mathrm{DM} / \mathrm{kg}$ fresh weight was slightly lower than that used in the previous experiment ( $222 \mathrm{~g} \mathrm{DM} / \mathrm{kg}$ fresh weight) but other constituents had not changed. The twenty common protein-bound amino acids (excluding tryptophan, cysteine, asparagine and glutamine) accounted for approximately 0.57 by weight of silage crude protein after correction for the water loss on formation of peptide bonds from amino acids.

\section{Rumen fermentation and passage of digesta to the duodenum}

Table 1 shows selected rumen indices of steers offered silage, either alone or with $150 \mathrm{~g}$ fishmeal supplement/kg silage DM. Fishmeal supplementation had no significant effect on rumen volume, liquid-phase fractional outflow rate or total rumen liquid outflow rate $(P>0.05)$. However it should be noted that because of missing values, the residual error for the first two of these variables was based on only 1 degree of freedom. Supplementation significantly $(P<0.01)$ increased the average rumen ammonia concentration but had no effect on $\mathrm{pH}$ or VFA profiles in the rumen.

The quantities of DM and OM consumed and entering the duodenum of steers offered the two diets are shown in Table 2. Although mean total intakes $(\mathrm{kg} / \mathrm{d})$ were similar for both diets, duodenal flows of both DM and OM were significantly increased on the 
Table 2. Intake and flow of digesta constituents at the duodenum of steers fed on silage with and without a fishmeal supplement

\begin{tabular}{|c|c|c|c|c|}
\hline & Silage & $\begin{array}{l}\text { Silage + } \\
\text { fishmeal }\end{array}$ & SED & $\begin{array}{c}\text { Statistical } \\
\text { significance } \\
\text { of difference }\end{array}$ \\
\hline \multicolumn{5}{|l|}{ Dry matter } \\
\hline Intake $(\mathrm{kg} / \mathrm{d})$ & $4 \cdot 02$ & 4.23 & 0.066 & NS \\
\hline Intake $(\mathrm{g} / \mathrm{kg} \mathrm{LW})$ & $21 \cdot 69$ & $23 \cdot 33$ & 0.287 & * \\
\hline At duodenum $(\mathrm{kg} / \mathrm{d})$ & 2.49 & 3.08 & $0 \cdot 107$ & * \\
\hline \multicolumn{5}{|l|}{ Organic matter } \\
\hline Intake $(\mathrm{kg} / \mathrm{d})$ & 3.73 & 3.87 & 0.059 & NS \\
\hline Intake $(\mathrm{g} / \mathrm{kg} \mathrm{LW})$ & $20 \cdot 10$ & 21.36 & 0.263 & $*$ \\
\hline At duodenum $(\mathrm{kg} / \mathrm{d})$ & $2 \cdot 01$ & 2.59 & 0.090 & $*$ \\
\hline OMADR $(\mathrm{kg} / \mathrm{d})$ & $1 \cdot 72$ & $1 \cdot 28$ & 0.033 & $* *$ \\
\hline DOMI $\dagger(\mathrm{kg} / \mathrm{d})$ & $2 \cdot 96$ & $3 \cdot 18$ & 0.050 & * \\
\hline OMADR: DOMI & 0.58 & 0.40 & 0.015 & $* *$ \\
\hline
\end{tabular}

OMADR, organic matter apparently digested in the rumen; DOMI, digestible organic matter intake; SED, standard error of difference between means ( $2 \mathrm{df})$; NS, not significant; LW, live weight.

$* P<0.05, * * P<0.01$.

$\dagger$ Using organic matter digestibility values obtained by D. E. Beever (unpublished results): digestibility for silage diet $0 \cdot 794$, silage + fishmeal 0.821 .

Table 3. Intake and flow of digesta constituents at the duodenum of steers fed on silage with and without a fishmeal supplement

\begin{tabular}{|c|c|c|c|c|}
\hline & Silage & $\begin{array}{l}\text { Silage + } \\
\text { fishmeal }\end{array}$ & SED & $\begin{array}{c}\text { Statistical } \\
\text { significance } \\
\text { of difference }\end{array}$ \\
\hline \multicolumn{5}{|c|}{ Total nitrogen $(\mathrm{g} / \mathrm{d})$} \\
\hline Intake & 91.9 & $136 \cdot 1$ & $2 \cdot 75$ & $* *$ \\
\hline At duodenum & $95 \cdot 2$ & $153 \cdot 7$ & $4 \cdot 90$ & $* *$ \\
\hline \multicolumn{5}{|c|}{ Non-ammonia $\mathrm{N}(\mathrm{g} / \mathrm{d})$} \\
\hline Intake & $83 \cdot 1$ & $127 \cdot 8$ & $2 \cdot 64$ & ** \\
\hline At duodenum & $82 \cdot 6$ & $133 \cdot 3$ & 3.89 & ** \\
\hline \multicolumn{5}{|c|}{ Total amino acids $\dagger(\mathrm{g} / \mathrm{d})$} \\
\hline Intake & $330 \cdot 0$ & 553.9 & $12 \cdot 0$ & ** \\
\hline At duodenum & $416 \cdot 3$ & 627.6 & $40 \cdot 9$ & * \\
\hline
\end{tabular}

SED, standard error of difference between means $(2 \mathrm{df})$.

$* P<0.05,{ }^{* *} P<0.01$.

$\dagger$ The twenty common protein-bound amino acids excluding tryptophan, cysteine, asparagine and glutamine, with corrections for water loss on formation of peptide bonds.

fishmeal-supplemented diet $(P<0.05)$. Intakes expressed per $\mathrm{kg}$ animal $\mathrm{LW}$ were also significantly higher on the fishmeal-supplemented diet $(P<0.05)$ although both intake levels were slightly lower than those reported by Gill et al. (1987).

Assuming OM digestibility values of 0.794 for silage alone and 0.821 for silage plus fishmeal (D. E. Beever, M. Gill, J. M. Dawson and P. J. Buttery, unpublished results obtained with the same frozen/thawed silage and similar animals under similar experimental conditions), intakes of digestible OM (DOMI) were calculated to be 
Table 4. Mean microbial $N$ flows $(g / d)$ in steers fed on silage with and without a fishmeal supplement

(Values represent the mean of estimates obtained with three markers: ${ }^{15} \mathrm{~N},\left[{ }^{3} \mathrm{H}\right]$ leucine and diaminopimelic acid (DAPA), and both rumen- and duodenally-derived microbes)

\begin{tabular}{lcccc}
\hline \hline & Silage & $\begin{array}{c}\text { Silage }+ \\
\text { fishmeal }\end{array}$ & SED & $\begin{array}{c}\text { Statistical } \\
\text { significance } \\
\text { of difference }\end{array}$ \\
\hline Microbial N flow & 51.9 & 68.7 & 3.39 & $*$ \\
\hline
\end{tabular}

SED, standard error of difference between means $(2 \mathrm{df})$.

* $P<0.05$.

Table 5. Estimates of microbial nitrogen flow $(\mathrm{g} / \mathrm{d})$ obtained with three different markers and using rumen- and duodenally-derived microbes

\begin{tabular}{lccc}
\hline & \multicolumn{3}{c}{ Marker } \\
\cline { 2 - 4 } Microbial source & ${ }^{15} \mathrm{~N}$ & {$\left[^{3}\right.$ H]leucine } & DAPA \\
\hline Rumen & $55 \cdot 8$ & $63 \cdot 2$ & $57 \cdot 1$ \\
Duodenum & $69 \cdot 2$ & $67 \cdot 3$ & $49 \cdot 5$ \\
\hline
\end{tabular}

DAPA, diaminopimelic acid.

Standard error of difference between means $(16 \mathrm{df})$ for comparing between locations $=3 \cdot 33$ and for comparing markers within the same location $=3.91$.

Although DAPA is strictly a bacterial protein marker and fails to account for the protozoal contribution to microbial $\mathrm{N}$, the term microbial has been used throughout to maintain consistency.

significantly higher $(P<0.05)$ on the fishmeal-supplemented diet, but a significantly $(P<0.01)$ reduced proportion of the digestible OM was apparently fermented in the rumen of steers consuming the supplemented silage. However, in both instances values were lower than general expectations for such diets (see Discussion).

Table 3 shows the intakes and duodenal flow of N, NAN and total amino acids on the two diets. Fishmeal supplementation increased the total $\mathrm{N}$ content of the diet from $22.8 \mathrm{~g}$ $\mathrm{N} / \mathrm{kg} \mathrm{DM}$ to $31.6 \mathrm{~g} \mathrm{~N} / \mathrm{kg} \mathrm{DM}$ and significantly $(P<0.01)$ increased total N, NAN and amino acid intake. Flows of total N, NAN and amino acids at the duodenum of animals consuming supplemented silage were significantly higher $(P<0.01, P<0.01, P<0.05$ respectively) than in those consuming silage alone.

\section{Microbial protein production by the rumen}

Effect of fishmeal supplementation. Estimates of microbial $\mathrm{N}$ flow at the duodenum were obtained with three different markers $\left({ }^{15} \mathrm{~N}, \mathrm{~L}-\left[4,5-{ }^{3} \mathrm{H}\right]\right.$ leucine and DAPA) and based on microbial fractions obtained from rumen and duodenal contents (Table 4). Overall mean estimates showed a significant $(P<0.05)$ increase in microbial $\mathrm{N}$ flow when the silage was supplemented with fishmeal. Irrespective of sampling site, estimates ranged between 39.7 and $60.9 \mathrm{~g} / \mathrm{d}$ for the silage diet (mean $52.0 \mathrm{~g} / \mathrm{d}$ ) and between 59.2 and $77.5 \mathrm{~g} / \mathrm{d}$ for the supplemented diet (mean $68.7 \mathrm{~g} / \mathrm{d}$ ).

Effect of different markers and microbial source. Estimates obtained with the three markers and the two microbial fractions, irrespective of diet, are shown in Table 5. There was a significant interaction between marker and microbial fraction $(P<0.01)$. Using protected $t$ tests, significant differences were found with ${ }^{15} \mathrm{~N}$ and DAPA estimates between 
Table 6. Efficiency of microbial protein synthesis $\dagger$ in steers fed on silage and fishmealsupplemented silage diets, the degradability of these diets and the nitrogen source used by the microbes

\begin{tabular}{|c|c|c|c|c|}
\hline & Silage & $\begin{array}{l}\text { Silage + } \\
\text { fishmeal }\end{array}$ & SED & $\begin{array}{c}\text { Statistical } \\
\text { significance } \\
\text { of difference }\end{array}$ \\
\hline \multicolumn{5}{|l|}{$\begin{array}{l}\text { Efficiency of microbial protein } \\
\text { synthesis }\end{array}$} \\
\hline g N/kg OMADR & 30.8 & $54 \cdot 3$ & $2 \cdot 03$ & $* *$ \\
\hline $\mathrm{g} \mathrm{N} / \mathrm{kg}$ OMTDR & 22.6 & 34.7 & 0.84 & $* *$ \\
\hline $\begin{array}{l}\text { Undegraded dietary protein } \\
\text { flow }(\mathrm{g} \mathrm{N} / \mathrm{d})\end{array}$ & $19 \cdot 3$ & $53 \cdot 3$ & $1 \cdot 40$ & $* *$ \\
\hline $\begin{array}{l}\text { RDN supplied } \\
\text { (g N/kg OMADR) }\end{array}$ & $42 \cdot 5$ & $65 \cdot 0$ & $2 \cdot 58$ & $*$ \\
\hline $\begin{array}{l}\text { Apparent efficiency of capture of } \\
\text { RDN by microbes }(\%)\end{array}$ & $72 \cdot 0$ & $83 \cdot 6$ & $2 \cdot 94$ & NS \\
\hline $\begin{array}{l}\text { Proportion of microbial } \mathrm{N} \text { from } \\
\text { rumen ammonia }\end{array}$ & 0.55 & 0.39 & 0.071 & NS \\
\hline $\begin{array}{l}\text { Proportion of microbial leucine } \\
\text { from direct incorporation } \\
\text { of leucine }\end{array}$ & 0.37 & 0.33 & 0.058 & NS \\
\hline
\end{tabular}

RDN, rumen-degradable $\mathrm{N}$, estimated from the $\mathrm{N}$ degradability values obtained from the equation:

$$
\mathrm{N} \text { degradability }=\mathrm{I}-\frac{\text { (NAN flow }- \text { microbial } \mathrm{N} \text { flow }- \text { endogenous } \mathrm{N} \text { flow) }}{\mathrm{N} \text { intake }},
$$

where endogenous $\mathrm{N}$ flow was assumed to be $11.3 \mathrm{~g} / \mathrm{d}$ (Bartram, 1987); OMADR, organic matter (OM) apparently digested in the rumen; OMTDR, OM truly digested in the rumen after accounting for microbial OM content of duodenal digesta (determined as $876 \mathrm{~g} \mathrm{OM} / \mathrm{kg}$ dry matter (DM) for silage diet and $867 \mathrm{~g} \mathrm{OM} / \mathrm{kg} \mathrm{DM}$ for silage + fishmeal); SED, standard error of difference between means ( $2 \mathrm{df}$ ); NS, not significant ; NAN, nonammonia $\mathrm{N}$.

* $P<0.05 . \quad * * P<0.01$

$\dagger$ Values for microbial $\mathrm{N}$ flow and efficiency of microbial protein synthesis represent the mean of estimates obtained with three markers, ${ }^{15} \mathrm{~N},\left[{ }^{3} \mathrm{H}\right]$ leucine and DAPA, and both rumen- and duodenally-derived microbes.

the two microbial sampling sites, duodenally-derived microbes giving significantly higher estimates than rumen microbial isolates with ${ }^{15} \mathrm{~N}(P<0 \cdot 001)$ and significantly lower estimates with DAPA $(P<0 \cdot 05)$. In contrast, estimates with $\left[{ }^{3} \mathrm{H}\right] l$ leucine were similar with both microbial sources $(P>0 \cdot 05)$.

There were no significant differences between the estimates obtained with the three markers in rumen-derived microbial fractions $(P>0.05)$. In microbial fractions isolated from duodenal digesta there was no significant difference between ${ }^{15} \mathrm{~N}$ and $\left[{ }^{3} \mathrm{H}\right]$ leucine estimates $(P>0.05)$, but both were significantly $(P<0.001)$ higher than DAPA estimates.

Efficiency of microbial protein synthesis. Fishmeal supplementation of silage significantly $(P<0.01)$ improved the efficiency of rumen microbial protein synthesis in terms of $\mathrm{OM}$ both apparently (OMADR) and truly (OMTDR) digested in the rumen (i.e. after accounting for microbial OM flow) (Table 6). The rumen degradable $N$ (RDN) (g/kg OMADR) supplied by the two diets was estimated assuming an endogenous $\mathrm{N}$ flow to the duodenum of $11.3 \mathrm{~g} / \mathrm{d}$ (Bartram, 1987) and the fishmeal-supplemented diet was found to supply significantly $(P<0.05)$ more RDN than silage alone. Although there was a trend for improved apparent efficiency of capture of RDN by the rumen microbes from 72 to 
$84 \%$ in animals offered the supplemented diet, the values did not attain statistical significance $(P>0.05$, Table 6$)$.

Source of microbial $N$. The use of labelled leucine and ${ }^{15} \mathrm{NH}_{3}$ to investigate differences in the source of $\mathrm{N}$ used by the microbes when silage diets were supplemented with fishmeal was confounded by mixing problems in the rumen causing considerable variation in values obtained both within- and between-animals, with consequent large associated errors. Reported results must therefore be interpreted with caution and the trends considered rather than absolute values. The results (Table 6) suggest that a lower proportion of rumen microbial $\mathrm{N}$ was derived from the rumen ammonia pool when fishmeal supplemented the silage diet, implying that a greater proportion of microbial $\mathrm{N}$ must be derived from preformed amino acids or peptides. Equally, the $\left[{ }^{3} \mathrm{H}\right]$ leucine values indicated that a significant proportion of microbial protein leucine was incorporated directly from the rumen free pool either as leucine or as a close metabolite (see p. 351). However, no significant differences $(P>0.05)$ were detected in the proportion derived from the rumen pool between the supplemented and unsupplemented silage diets.

\section{DISCUSSION}

The silage and fishmeal offered were taken from the same clamp and batch as those used in the experiment reported by Gill et al. (1987) to ensure a relevant comparison. The silage was stored frozen at $-20^{\circ}$ until required and was found to have a slighly lower DM content $(206 \mathrm{~g} / \mathrm{kg}$ fresh weight) than the silage used in the first experiment $(222 \mathrm{~g} / \mathrm{kg}$ fresh weight), whilst all other chemical components were unchanged. Fishmeal was added at $150 \mathrm{~g} / \mathrm{kg}$ silage DM, the highest level of supplement used in the first experiment and one which elicited mean increases of approximately $0.25 \mathrm{~kg} \mathrm{LW}$ gain $/ \mathrm{d}$ over the control animals offered silage alone (average daily LW gain, $0.77 \mathrm{~kg} / \mathrm{d}$ ) (Gill et al. 1987).

The animals were obtained from the same stock as those used by Gill et al. (1987) and were at a similar stage of growth. In the present study the animals were offered feed hourly from belt-feeders, the total daily amount offered $(24 \mathrm{~g} \mathrm{DM} / \mathrm{kg} \mathrm{LW})$ being equivalent to the feed consumed by animals in the first trial when fed ad lib. However some feed refusals were recorded, especially with the unsupplemented diet. Gill et al. (1987) found no difference in voluntary intake between the two groups, whereas in the present study animals receiving the fishmeal-supplemented diet consumed significantly more than those receiving silage alone. These differences between studies could be due to the freezing and thawing of the silage which is known to reduce the solubility of $\mathrm{N}$ components in high-quality herbages (Beever et al. 1974a; MacRae et al. 1975). It is also possible that the continuous rather than once-daily feeding regimen may have influenced the voluntary feed intake of the animals. The possibility also cannot be excluded that the lower feed intake levels were affected by the housing regime and the surgical modifications that these animals had been subjected to.

\section{$O M$ digestion}

Digestibility of silage is sometimes improved by low levels of fishmeal supplementation (Gill \& England, 1984; England \& Gill, 1985; Oldham et al. 1985). Oldham et al. (1985) reported a progressive increase in the digestibility of DM, OM and cell-wall constituent fractions on replacing urea- $\mathrm{N}$ with fishmeal $\mathrm{N}$ in the rations of lactating dairy cows and suggested that this effect could, in part, be explained by changes in the fibre digestion in the rumen. Gill et al. (1987) reported no such digestibility effect of fishmeal on the silage used in the present study, which is presumably a consequence of the already high digestibility of the unsupplemented silage (OM digestibility 0.794). However, it is also possible that any increase in digestibility which may have occurred with the lower levels of fishmeal 
supplementation may have been lost with excess fishmeal $(150 \mathrm{~g} / \mathrm{kg}$ silage $\mathrm{DM})$. Interestingly, in a recent digestion experiment using the same frozen and thawed silage as that in the present experiment, an increase in OM digestibility was obtained with $150 \mathrm{~g}$ fishmeal $/ \mathrm{kg}$ total DM $(0.821)$ compared with the unsupplemented silage (0.794) (D. E. Beever, M. Gill, J. M. Dawson and P. J. Buttery, unpublished results). By applying these digestibility values to the present study, fishmeal supplementation appeared significantly to reduce the proportion of DOMI which was apparently fermented in the rumen. This apparent shift in the site of OM digestion has been reported in previous studies with fishmeal-supplemented silage diets (Gill \& Beever, 1982; Cottrill et al. 1982). However, the proportion of DOMI which was apparently fermented in the rumen on the silage diet in the present study $(0 \cdot 58)$ was lower than that generally obtained for silages $(0 \cdot 60-0 \cdot 70$, Beever et al. 1977; Unsworth \& Stevenson, 1978; Thomas et al. 1980 b; Thomson et al 1981; Chamberlain et al. 1982, 1986). Interestingly, Beever et al. (D. E. Beever, M. Gill, J. M. Dawson and P. J. Buttery, unpublished results), using the same techniques to measure digesta flow, obtained values for the proportional digestion of OM in the rumen of 0.72 and 0.60 respectively for the silage-only and fishmeal-supplemented diets when fed twice daily to similar animals. These differences are not easily reconciled in view of the consistency of diet and flow measurement technique between the two experiments. However, it is reasonable to conclude at this stage that the use of $\mathrm{Yb}$ and CrEDTA as flow markers was not responsible for the low values reported in the present study. Few studies have been reported where silage diets have been fed both continuously and twice daily. Reasons for the differences between these two studies obviously require further investigation.

The apparent proportional depression of OM digestion in the rumen when fishmeal is added to silage diets probably occurs because fishmeal is, in general, a highly digestible protein source yet is relatively resistant to rumen degradation (Agricultural Research Council, 1980). However, even if the fishmeal supplement was $100 \%$ digestible but totally rumen undegradable, it could not wholly account for the apparent shift in OM digestion. A second possible explanation for this observation is that the OMADR values take no account of the flow of microbial $O M$ to the duodenum. These flows tended to be higher on the fishmeal-supplemented diet $(652 \mathrm{~g} / \mathrm{d}$ compared with $529 \mathrm{~g} / \mathrm{d}$ on the unsupplemented diet, $P=0.052$ ) which consequently resulted in a greater underestimation of the OMTDR of the supplemented diet (OMTDR:DOMI 0.761 for the unsupplemented diet and 0.607 for the fishmeal-supplemented diet, $P<0.01$ ).

\section{Digestion and flow of nitrogenous constituents}

Flow of $N$ to the duodenum. Supplementation of grass silage with $150 \mathrm{~g}$ fishmeal $/ \mathrm{kg}$ silage DM significantly increased the flow of both NAN and total amino acids to the duodenum of young cattle in the present study. Gill \& Beever (1982) reported similar findings with $100 \mathrm{~g}$ fishmeal supplement $/ \mathrm{kg}$ silage DM but no effect with lower $(50 \mathrm{~g})$ levels of supplementation. There was no loss of $\mathrm{N}$ across the forestomachs with either diet, but a net gain of almost $18 \mathrm{~g} \mathrm{~N} / \mathrm{d}$ with the fishmeal-supplemented diet. $\mathrm{N}$ losses of between 5 and $35 \%$ of $\mathrm{N}$ intake have been reported for cattle (Rooke et al. 1982; Chamberlain et al. 1986) and sheep (Siddons et al. 1985a) offered silage diets. Such inefficient utilization of silage N is conventionally attributed to the rapid and extensive rumen degradation of silage nonprotein-N (NPN) and soluble protein-N, resulting in high rumen ammonia concentrations (Fatianoff et al. 1966), inefficient microbial capture of this RDN (Beever \& Gill, 1987) and associated losses of ammonia across the rumen wall with subsequent excretion in the urine (Wilkins, 1974). Chamberlain et al. (1986) related $\mathrm{N}$ loss from the rumen of silage-fed cattle to increasing rumen ammonia concentrations. However, in the present study, rumen ammonia concentrations were lower than those reported by Chamberlain et al. (1986) and 
the apparent efficiency of capture of silage RDN by the rumen microbes was relatively high $(72 \%)$. This suggests that in the present experiment synchronization of energy and $\mathrm{N}$ release in the rumen was improved and a net loss of $\mathrm{N}$ anterior to the duodenum was thereby prevented. At least part of this may be due to the continuous-feeding regimen employed.

Both the supplemented and unsupplemented silage diets were associated with net gain of amino acids between the mouth and duodenum, due to de novo synthesis by the rumen microbes. The increase in flow of NAN to the duodenum in response to fishmeal supplementation was due both to an increased flow of undegraded dietary $\mathrm{N}$ and an increased flow of microbial $\mathrm{N}$. The increase in duodenal amino acid flow due to fishmeal (approximately $210 \mathrm{~g} / \mathrm{d}$ ) could be expected to support an additional protein gain of approximately $110 \mathrm{~g} / \mathrm{d}$ in those animals receiving the supplemented diet according to the calculations of the Agricultural Research Council (1980). In the experiment of Gill et al. (1987), protein gain in the empty body of animals fed on fishmeal-supplemented silage ( $150 \mathrm{~g}$ fishmeal $/ \mathrm{kg}$ silage DM) was estimated to be approximately $50 \mathrm{~g} / \mathrm{d}$ greater than those fed on silage alone. Taking into account differences between animals and experiments, this would suggest an efficiency of retention of increased protein of approximately 0.24 which is considerably lower than the value of 0.53 suggested by the Agricultural Research Council (1980).

Synthesis of microbial $N$. Fishmeal supplementation of the silage significantly increased microbial $\mathrm{N}$ flow at the duodenum and contributed approximately $33 \%$ to the increased duodenal NAN flow. In contrast, no increase in microbial $\mathrm{N}$ flow was observed when these diets were fed twice daily (D. E. Beever, M. Gill, J. M. Dawson and P. J. Buttery, unpublished results). Thus the increase in microbial $\mathrm{N}$ flow in response to fishmeal supplementation obtained in the present study must reflect the more continuous supply of nitrogenous substrates for microbial growth when the animals were fed hourly.

Several methods are available to estimate the flow of microbial $\mathrm{N}$ to the duodenum of ruminants (Ling \& Buttery, 1978; Beever et al. 1974 b; Mathers \& Miller, 1980; Siddons et al. 1982), all of which rely on a common principle of determining the ratio marker : $\mathrm{N}$ in a pure microbial fraction assumed to be representative of the total microbial population, and the dilution of marker in whole duodenal digesta. Estimates of microbial $\mathrm{N}$ flow have been shown to vary with the marker chosen and the source of the microbial isolate (Ling \& Buttery, 1978; Stern \& Hoover, 1979; Siddons et al. 1982; Kennedy et al. 1984).

Estimates of microbial $\mathrm{N}$ flow obtained with the three markers used in the present study showed similar trends between the unsupplemented and fishmeal-supplemented diets, but gave different absolute values which consequently resulted in different estimates of microbial protein synthesis and dietary $\mathrm{N}$ degradability values. Mean values were therefore used to calculate these variables. However, some explanations for the differences in estimates between markers and between microbial sources can be advanced.

Siddons et al. (1982) stated that 'in order to obtain reliable estimates of microbial $\mathrm{N}$ using the marker-dilution technique, either the marker must be uniformly distributed throughout all microbial species or the isolated microbial fraction must be representative of those microbial species leaving the rumen'. As DAPA does not fulfil the first of these criteria (Dufva et al. 1982), its accuracy relies on the second. However, isolation of representative microbial fractions is difficult. Three distinct microbial populations exist within the rumen associated (1) with the fluid phase, (2) with particulate material and (3) attached to the rumen epithelium (Cheng et al. 1979). It is unlikely that either of the latter two populations is sampled adequately by the procedures normally used for the collection of rumen fluid. Sampling of digesta at the duodenum allows collection of all material entering the small intestine and thereby theoretically provides a more representative 
microbial fraction. However, differences in susceptibility to lysis are likely to exist between microbial species. Isolation of the microbial fractions by differential centrifugation will result in the loss of some protozoa and particle-bound bacteria in low-speed centrifugation steps (Siddons et al. 1982). Incorporation of rumen-infused isotopic labels may vary with microbial species and between free-floating and adherent populations. The degree of modification of the microbes by lysis or proteolytic attack during passage from the rumen through the abomasum is unknown, but morphological differences have been observed between rumen and duodenal microbes (Mathers \& Miller, 1980). An increased proportion of lysed or damaged cells in microbial fractions isolated from duodenal digesta will increase DAPA: $\mathrm{N}$ values in these fractions and consequently underestimate microbial $\mathrm{N}$ flow which may explain the difference in estimates obtained with this marker between the two sampling sites.

In several reports, ${ }^{35} \mathrm{~S}$ specific activity and ${ }^{15} \mathrm{NAN}$ enrichment tend to be lower in duodenal microbial fractions than rumen fractions with consequently higher estimates of microbial $\mathrm{N}$ flow from the former fractions (Mathers \& Miller, 1980; Siddons et al. 1982; Kennedy et al. 1984). This was also found in the present study with ${ }^{15} \mathrm{~N}$. These findings may be explained, at least in part, if bacteria attached to food particles are less extensively labelled than those floating free in the fluid phase. No significant differences were detected in the specific activities of $\left[{ }^{3} \mathrm{H}\right]$ leucine in rumen and duodenal microbial isolates which suggests that this marker is incorporated by all microbial populations and throughout their proteins. This consistency of estimate of microbial $\mathrm{N}$ flow between sampling sites may be one of the advantages of $\left[{ }^{3} \mathrm{H}\right]$ leucine over the other two markers used in the present study.

The estimates of microbial protein synthesis obtained with $\left[{ }^{3} \mathrm{H}\right]$ leucine were comparable $(P>0.05)$ to those obtained with ${ }^{15} \mathrm{~N}$ in both rumen and duodenal microbes and with DAPA estimates from rumen microbes. However, this novel marker has a number of practical and theoretical advantages which recommend it as a useful alternative microbialprotein marker. The major cellular role of leucine is in protein synthesis and as such $\mathrm{L}-\left[4,5-{ }^{3} \mathrm{H}\right]$ leucine is a true protein marker. In contrast, ${ }^{15} \mathrm{~N}$ is incorporated into both proteins and nucleic acids. Furthermore, unlike DAPA, leucine is present in the protein of all microbial species (including protozoa) and is distributed throughout the cell, thereby satisfying, at least theoretically, the first criteria stated by Siddons et al. (1982). The $\left[4,5{ }^{3} \mathrm{H}\right]$-labelling effectively follows the carbon skeleton of the leucine molecule and on its catabolism, the ${ }^{3} \mathrm{H}$ label is rapidly lost to the water pool, thereby reducing the problems of label recycling associated with other isotopic markers (e.g. $\left.{ }^{15} \mathrm{~N}\right)$. The method of assay for the leucine marker is technically simple and requires no sophisticated equipment other than a liquid scintillation counter as over $98 \%$ of the total activity in a well-washed protein hydrolysate is associated with the leucine fraction thereby making fractionation of the sample unnecessary. There is little free leucine in the digesta: from measurement of the total leucine balance across the rumen it can be calculated that more than $97 \%$ of the label arriving at the duodenum is of microbial origin. Other advantages of $\mathrm{L}-\left[4,5-{ }^{3} \mathrm{H}\right]$ leucine over alternative isotopic markers include its stability, safety and cost.

Dietary $N$ degradability. Nitrogen degradability in the two diets was calculated by difference from the quantity of undegraded dietary $\mathrm{N}$ flowing at the small intestine after allowing for microbial and endogenous $\mathrm{N}$ flow. Mean microbial $\mathrm{N}$ flows were 52 and $69 \mathrm{~g} \mathrm{~N} / \mathrm{d}$ for the unsupplemented and supplemented diets respectively, accounting for 63 and $52 \%$ respectively of the duodenal NAN flow. Endogenous $\mathrm{N}$ contributions of $11.3 \mathrm{~g}$ $\mathrm{N} / \mathrm{d}$, assumed for both diets, were determined by direct measurement of endogenous protein in steers of similar age fed on fishmeal-supplemented silage (Bartram, 1987). These values are within the range estimated by other workers for cattle $(4 \cdot 9-9 \cdot 6$, Ørskov \& MacLeod, 1983; 5·8-13·5, Ørskov et al. 1986; 21·0, Brandt et al. 1984). 
Silage $\mathrm{N}$ degradability in the present study was estimated to be approximately 0.80 , which is similar to values obtained by other workers for formic acid-treated ryegrass silages $(0 \cdot 91$, Rooke et al. $1983 a ; 0.82$, Rooke et al. $1983 b)$ and considerably higher than estimates generally obtained for silages prepared without additive $(0.52$, Thomson et al. $1981 ; 0.69$, Brett et al. 1979). Degradability of $\mathrm{N}$ in the fishmeal-supplemented diet was significantly lower $(0.61)$ than in the unsupplemented diet $(P<0.01)$. Thus the supply of undegraded dietary $\mathrm{N}$ to the duodenum was significantly increased from $19 \cdot 3 \mathrm{~g} / \mathrm{d}$ to $53.3 \mathrm{~g} / \mathrm{d}$ by fishmeal supplementation. Expressed relative to the increase in dietary $\mathrm{N}$ intake due to fishmeal and assuming that the degradability of silage $\mathrm{N}$ is not influenced by the presence of fishmeal in the diet it can be estimated that approximately $70 \%$ of the fishmeal $\mathrm{N}$ escaped degradation in the rumen. This value agrees well with estimates of fishmeal degradability obtained by other workers (Hume, 1974; Mercer et al. 1980).

\section{Efficiency of microbial protein synthesis}

Fishmeal supplementation of grass silage significantly improved the efficiency of rumen microbial protein synthesis in the present study in agreement with the observations of Cottrill et al (1982) with maize silage. The value obtained for the efficiency of microbial protein synthesis on the unsupplemented silage diet (30.8 $\mathrm{g} \mathrm{N} / \mathrm{kg}$ OMADR) is relatively high compared with values obtained by many other workers. Silage diets are often associated with low microbial protein yields in the rumen $(26.7 \mathrm{~g} \mathrm{~N} / \mathrm{kg}$ OMADR, Beever et al. 1977; 21.6, Siddons et al. 1979; 22.7, Thomas et al. 1980a) which may in part be explained by the fact that a proportion of the digestible organic matter in silage is present as fermentation end-products which have a relatively low energy yield on rumen fermentation.

It has also been suggested that microbial protein synthesis may be limited by inefficient capture of RDN because of poor synchronization of energy yield and $\mathrm{N}$ release in the rumen (Chamberlain \& Thomas, 1980). Our findings show that this inefficiency may be substantially reduced if the silage is of good quality and is offered hourly. Nevertheless, microbial protein synthesis on the silage diet was limited by either RDN supply or composition since fishmeal supplementation enhanced synthetic efficiency $(P<0.01)$, yet the apparent efficiency of capture of RDN was not significantly increased (but see comments under Statistical analysis).

\section{Source of microbial $N$}

Several workers using intrarumen infusions of ${ }^{15} \mathrm{~N}$-labelled ammonium salts to label rumen ammonia have suggested that considerable proportions $(0 \cdot 20-0 \cdot 60)$ of rumen microbial $\mathrm{N}$ may be derived from sources other than ammonia (Kennedy \& Milligan, 1978; Siddons et al. 1985a; Dixon \& Nolan, 1986). These conclusions are based on the assumption that any $\mathrm{N}$ that is incorporated into the microbial $\mathrm{N}$ which has not equilibrated with the rumen ammonia pool, i.e. is not labelled with ${ }^{15} \mathrm{~N}$, must have originated from direct incorporation of amino acids and peptides. The technique does not accommodate the possible effects of exchange of the amino group between the ammonia pool and preformed amino acids via transamination. Development of the intraruminal $\mathrm{L}-\left[4,5{ }^{3} \mathrm{H}\right]$ leucine-infusion technique by Bruce et al. (1985) enables the extent of direct incorporation of the preformed carbon skeleton of leucine into rumen microbial protein to be determined. The technique measures the proportion of microbial leucine directly incorporated from the rumen free pool as the free amino acid and possibly also as branched-chain fatty acids. It does not accommodate peptide uptake.

As with most isotopic methods involving continuous infusion of tracer into the rumen, the success of the technique depends on the establishment of steady-state conditions in the rumen. Unfortunately, considerable variability in the estimates of leucine specific activity 
in the rumen free pool and the ${ }^{15} \mathrm{~N}$ enrichment of rumen ammonia were encountered which were attributed to inadequate mixing in the rumen. This problem was compounded because although the diets were offered hourly, the animals tended to allow feed to accumulate before consuming it in distinct meals. This meant that true steady-state conditions were not attained, reflected by the range in concentration of free leucine (6-100 $\mu \mathrm{M})$, ammonia $(3-17 \mathrm{~mm})$ and $\mathrm{Cr}(6-16 \mathrm{ppm})$ measured in rumen digesta. However, it was still possible to obtain estimates for the specific activities of the rumen free pool and the rumen ${ }^{15} \mathrm{NH}_{3}$ enrichment and thereby assess the importance of preformed leucine and ammonia as precursors for rumen microbial protein synthesis. Similar rumen mixing problems have been reported by Bruce $e t$ al. (1987) in sheep given roughage and were greater with continuous rather than intermittent feeding.

Siddons et al. $(1985 a)$ determined that $65 \%$ of microbial $\mathrm{N}$ synthesized in the rumen of sheep offered silage was derived from ammonia. The results of the present study would suggest a slightly lower proportion was derived from ammonia with this silage (approximately 0.55 ). The proportion of microbial $\mathrm{N}$ arising from the rumen ammonia pool tended to be reduced when the silage was supplemented with fishmeal but no differences were observed in the proportion of leucine directly incorporated between supplemented and unsupplemented diets. This could indicate increased incorporation of peptide-bound amino acids in response to fishmeal supplementation. However, peptide uptake could not be measured directly.

In conclusion, the present study has shown that efficient utilization of $\mathrm{N}$ and high rates of rumen microbial protein synthesis were attained when high quality ryegrass silage was offered hourly from automatic belt feeders to young, growing steers. Fishmeal supplementation of such diets increased the supply of NAN at the duodenum as a result of increased flows of both microbial and undegraded dietary protein fractions, and could substantially account for growth responses observed in steers offered the supplemented silage (Gill et al. 1987).

The authors wish to thank Mr M. Lammiman and Mr S. Frith for technical assistance. Most of this work was conducted as part of an AFRC-linked research programme whose support is gratefully acknowledged. C.I.B. held an SERC CASE studentship in conjunction with Unilever Research Laboratories.

\section{REFERENCES}

Agricultural Research Council (1980). The Nutrient Requirements of Ruminant Livestock. Farnham Royal: Commonwealth Agricultural Bureaux.

Atkin, G. E. \& Ferdinand, W. (1970). Analytical Biochemistry 38, 313-329.

Bartram, C. G. (1987). The endogenous protein content of ruminant proximal duodenal digesta. PhD Thesis, University of Nottingham.

Beever, D. E., Cammell, S. B. \& Wallace, A. S. (1974a). Proceedings of the Nutrition Society 33, 73A.

Beever D. E., \& Gill, M. (1987). In Recent Advances in Animal Nutrition-1987, pp. 173-185 [W. Haresign and D. J. A. Cole, editors]. London: Butterworths.

Beever, D. E., Harrison, D. G., Thomson, D. J., Cammell, S. B. \& Osbourn, D. F. (1974b). British Journal of Nutrition 32, 99-112.

Beever, D. E., Kellaway, R. C., Thomson, D. J., MacRae, I. C., Evans, L. C. \& Wallace, A. S. (1978). Journal of Agricultural Science, Cambridge 90, 157-163.

Beever, D. E., Thomson, D. J., Cammell, S. B. \& Harrison, D. G. (1977). Journal of Agricultural Science, Cambridge 88, $61-70$.

Binnerts, W. T., Van't Klooster, A. T. \& Frens, A. M. (1968). Veterinary Records 82, 470-477.

Brandt, M., Rohr, K. \& Lebzein, P. (1984). In The VIth International Symposium on Amino Acids, Serock, Poland, pp. 409-413. [T. Zebrowska, L. Burtaczewska, S. Buraczewski, J. Kowalczyk and B. Pastuszewska, editors]. Warsaw: Polish Scientific Publishers.

Brett, P. A., Almond, M., Harrison, D. G., Rowlinson, P., Rooke, J. \& Armstrong, D. G. (1979). Proceedings of the Nutrition Society 38, 148A. 
Bruce, C. I. (1986). Metabolism of preformed amino acids by rumen bacteria in vivo. PhD Thesis, University of Nottingham.

Bruce, C. I., Marsden, M. \& Buttery, P. J. (1985). Proceedings of the Nutrition Society 44, 143A

Bruce, L. A., Lobley, G. E. \& MacRae, J. C. (1987). Research in Veterinary Science 42, 47-52.

Chamberlain, D. G. \& Thomas, P. C. (1980). In Proceedings of 3rd European Association of Animal Production Symposium on Protein Metabolism and Nutrition, pp. 422-431, EAAP Publication no. 27 [H. J. Oslage and

K. Rohr, editors]. FR Germany: Information Centre of Bundesforschungsanstalt für Landwirtschaft.

Chamberlain, D. G., Thomas, P. C. \& Quig, J. (1986). Grass \& Forage Science 41, 31-38.

Chamberlain, D. G., Thomas, P. C. \& Wait, M. K. (1982). Grass \& Forage Science 37, 159-164.

Cheng, K.-J., McCowan, R. P. \& Costerton, J. W. (1979). American Journal of Clinical Nutrition 32, $139-148$.

Cottrill, B. R., Beever, D. E., Austin, A. R. \& Osbourn, D. F. (1982). British Journal of Nutrition 48, 527-54I.

Davidson, J., Mathieson, J. \& Boyne, A. W. (1970). Analyst 95, 181-193.

Dawson, J. M., Bruce, C. I., Lammiman, M. J., Buttery, P. J., Gill, E. M. \& Beever, D. E. (1987). Proceedings of the Nutrition Society 46, 37A.

Dixon, R. M. \& Nolan, J. V. (1986). British Journal of Nutrition 55, 313-332.

Dufva, G. S., Bartley, E. E., Arambel, M. J., Nagaraja, T. G., Dennis, S. M., Galitzer, S. J. \& Dayton, A. D. (1982). Journal of Dairy Science 65, 1754-1759.

England, P. \& Gill, M. (1985). Animal Production 40, 259-265.

Faichney, G. J. (1975). In Digestion and Metabolism in the Ruminant, pp. 277-291. [I. W. McDonald and A. C. I, Warner, editors]. Armidale, NSW: University of New England Publishing Unit.

Fatianoff, N., Durand, M., Tisserand, J. L. \& Zelter, S. Z. (1966). In Proceedings of the 10th International Grassland Congress, Helsinki, pp. 551-555 [A. G. G. Hill, V. U. Mustonen, S. Pulli and M. Latvala, editors]. Helsinki: Valtioneuvoston Kirjapaino.

Forbes, T. J. \& Irwin, J. H. D. (1970). Journal of the British Grassland Society 25, 96-103.

Garstang, J. R., Thomas, C. \& Gill, M. (1979). Animal Production 28, 423 (Abstr.).

Gill, M. \& Beever, D. E. (1982). British Journal of Nutrition 48, 37-47.

Gill, M., Beever, D. E., Buttery, P. J., England, P., Gibb, M. J. \& Baker, R. D. (1987). Journal of Agricultural Science, Cambridge 108, 9-16.

Gill, M. \& England, P. (1984). Animal Production 39, 31-36.

Hume, I. D. (1974). Australian Journal of Agricultural Research 25, 155-165.

Kennedy, P. M., Hazlewood, G. P. \& Milligan, L. P. (1984). British Journal of Nutrition 52, 403-417.

Kennedy, P. M. \& Milligan, L. P. (1978). British Journal of Nutrition 39, 105-117.

Ling, J. R. \& Buttery, P. J. (1978). British Journal of Nutrition 39, 165-179.

McDougall, E. I. (1948). Biochemical Journal 43, 99-109.

MacRae, J. C., Campbell, D. R. \& Eadie, J. (1975). Journal of Agricultural Science, Cambridge 84, $125-131$.

Mathers, J. C. \& Miller, E. L. (1980). British Journal of Nutrition 43, 503-514.

Mercer, J. R., Allen, S. A. \& Miller, E. L. (1980). British Journal of Nutrition 43, 421-433.

Oldham, J. D., Napper, D. J., Smith, T. \& Fulford, R. J. (1985). British Journal of Nutrition 53, 337-345.

Orskov, E. R. \& MacLeod, N. A. (1983). Proceedings of the Nutrition Society 42, 61A.

Ørskov, E. R., MacLeod, N. A. \& Kyle, D. J. (1986). British Journal of Nutrition 56, 241-248.

Rooke, J. A., Brookes, I. M. \& Armstrong, D. G. (1982). In Forage Protein in Ruminant Animal Production, British Society of Animal Production Occasional Publication no. 6, pp. 185-186. [D. J. Thomson, D. E. Beever and R. G. Gunn, editors]. Thames Ditton: British Society of Animal Production.

Rooke, J. A., Brookes, I. M. \& Armstrong, D. G. (1983a). Journal of Agricultural Science, Cambridge 100, $329-342$.

Rooke, J. A., Griefe, H. A. \& Armstrong, D. G. (1983 b). Grass \& Forage Science 38, 301-310.

Ryan, P. J. (1980). Analytical Biochemistry 108, 374-384.

Siddons, R. C., Beever, D. E. \& Nolan, J. V. (1982). British Journal of Nutrition 48, 377-389.

Siddons, R. C., Evans, R. T. \& Beever, D. E. (1979). British Journal of Nutrition 42, 535-545.

Siddons, R. C., Nolan, J. V., Beever, D. E. \& MacRae, J. C. (1985a). British Journal of Nutrition 54, $175-187$.

Siddons, R. C., Paradine, J., Beever, D. E. \& Cornell, P. R. (1985b). British Journal of Nutrition 54, 509-519.

Steen, R. W. J. (1985). Animal Production 41, 293-300.

Stern, M. D. \& Hoover, W. H. (1979). Journal of Animal Science 49, 1590-1603.

Thomas, P. C., Chamberlain, D. G., Kelly, N. C. \& Wait, M. K. (1980a). British Journal of Nutrition 43, $469-479$.

Thomas, P. C., Kelly, N. C., Chamberlain, D. G. \& Wait, M. K. (1980b). British Journal of Nutrition 43, $481-489$.

Thomson, D. J., Beever, D. E., Lonsdale, C. R., Haines, M. J., Cammell, S. B. \& Austin, A. R. (1981). British Journal of Nutrition 46, 193-207.

Unsworth, E. F. \& Stevenson, M. H. (1978). Record of Agricultural Research 26, 63-68.

Wilkins, R. J. (1974). In: University of Nottingham Nutrition Conference for Feed Manufacturers, no. 8, pp. 167-189 [H. Swan and D. Lewis editors]. London: Butterworths. 